\title{
Does the vaginal wall become thinner as prolapse grade increases?
}

\author{
Rhiannon Bray $^{1}$ (D) Alex Derpapas ${ }^{1} \cdot$ Ruwan Fernando $^{1} \cdot$ \\ Vik Khullar $^{1}$ • Demetri C. Panayi ${ }^{2}$
}

Received: 1 July 2016 / Accepted: 1 September 2016/Published online: 27 September 2016

(C) The Author(s) 2016. This article is published with open access at Springerlink.com

\begin{abstract}
Introduction and hypothesis The pathophysiology of prolapse is not well understood. However, two main theories predominate: either the fibromuscular layer of the vagina develops a defect/tears away from its supports, or its tissues are stretched and attenuated. The aim of this study was to assess how vaginal wall thickness (VWT) is related to vaginal prolapse. Methods The study group comprised 243 women with symptomatic prolapse recruited from the Outpatient Department of a tertiary referral centre for urogynaecology. A history was taken and women were examined to determine their POP-Q score. Using a previously validated technique, ultrasonography was used to measure the mean VWT at three anatomical sites on the anterior and posterior walls. Scores were then compared using $t$ tests, the Kruskal-Wallis test and the Friedman test.

Results The mean age of the patients was 59.7 years (SD 12.0 years range $38-84$ years). For each measurement VWT reduced as prolapse grade increased until the prolapse extended beyond the hymen. Women with grade 3 prolapse had a significantly higher mean VWT than women with grade 1 or 2 contained prolapse. Menopause status did not have a significant effect on the VWT.
\end{abstract}

This abstract was presented at the 2016 IUGA Scientific Meeting and has been accepted for fast track publication.

Rhiannon Bray

rhiannon.bray1@nhs.net

1 Department of Urogynaecology, St Mary's Hospital, Imperial NHS Trust, London W2 1NY, UK

2 Department of Urogynaecology, Pelvic Floor and Childbirth Injury, Epsom and St. Helier NHS Trust, Carshalton, UK
Conclusions VWT is lower in women with vaginal prolapse until the prolapse extends beyond the hymen and then VWT is thicker and comparable with women without prolapse. This may be explained by changes in the vaginal tissue including reduction of collagen, elastin and smooth muscle, as well as fibrosis in exposed tissues, rather than by defects in the vagina.

Keywords Prolapse $\cdot$ Ultrasonography $\cdot$ Vaginal wall thickness

\section{Introduction}

Pelvic organ prolapse (POP) is a common condition, defined as the descent of the pelvic organs (bladder, urethra, vagina, uterus, small bowel or rectum) secondary to deficiencies in the pelvic support system [1]. The exact prevalence is difficult to define but current estimates suggest that a woman's life-time risk for prolapse surgery is as high as $20 \%$ by the age of 80 years [2]. Despite the high prevalence and significant impact on quality of life, little is known about the pathophysiology of prolapse [2-5]. It is understood to be multifactorial with age, parity, weight, collagen weakness, and molecular and genetic influences all contributing [6]. On an anatomical level, two main causative theories predominate. The defect theory proposes that discrete tears in the fibromuscular wall of the vagina or detachments from their adjacent support tissues lead to POP [7, 8]. This has been contested by an alternative theory that the vaginal wall and its supports are stretched or attenuated [9]. These two theories could be tested by measuring vaginal wall thickness (VWT) and having consistency of thickness.

The vaginal wall itself is composed of three layers: epithelium, muscularis and adventitia [10]. The epithelium is 
Fig. 1 Study flow chart showing exclusion criteria, intervention and analysis

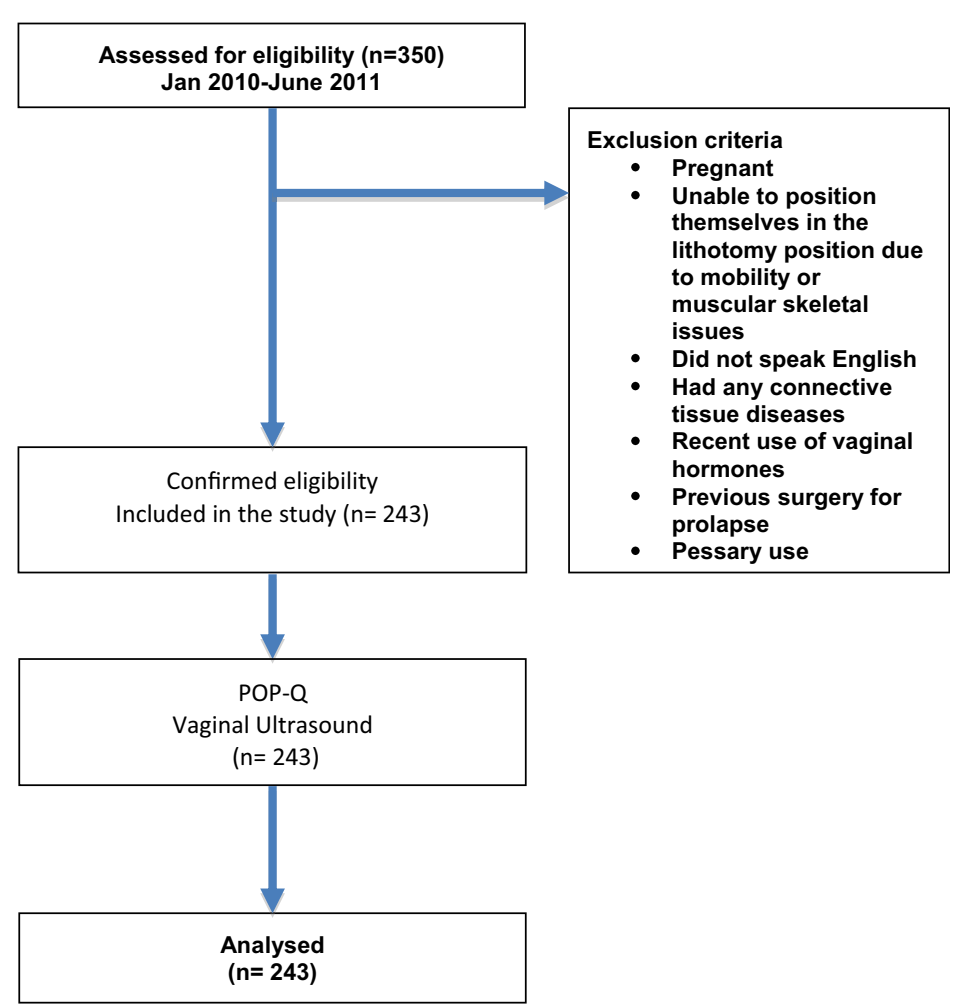

nonkeratinized, nonsecretory, stratified squamous epithelium, the muscularis is primarily smooth muscle with small amounts of collagen and elastin, and the outer adventitia is a fascial layer of connective tissue which includes collagen, elastin, adipose tissue, blood vessels and nerves. The fascia can be further divided into two types: the parietal fascia which covers the muscles and whose attachments to the vagina are referred to as endopelvic fascia, and the visceral fascia which covers the organs [11]. Anteriorly the vaginal wall is related to the base of the bladder and the urethra, and the fascia is referred to as the pubocervical fascia, and posteriorly the rectovaginal fascia separates the vagina from the rectum and the perineal body [12]. Little is known about the response of the vaginal wall to the pressure of prolapse, but weakening of these tissues is thought to be a contributing factor. The attenuation theory suggests that the tissues become thinner as they are stretched; this would not be expected in the defect theory [12].

Transvaginal ultrasonography has long been used for measurements within the pelvis [13]. Our technique for the measurement of VWT is highly reproducible and has been validated against the gold standard of histology [14]. The
Fig. 2 Ultrasound image showing measurement of vaginal wall thickness at the level of the bladder neck $i$ and the anorectal junction $i i$

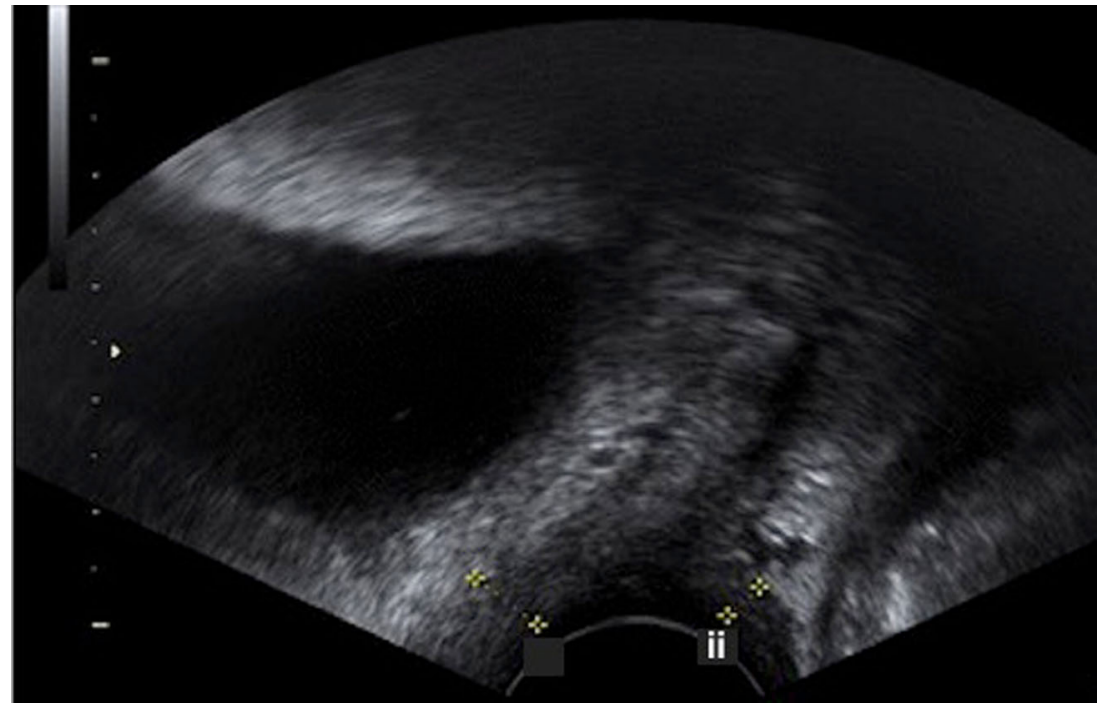


measurement can be taken in real time conferring an advantage over other imaging modalities and histopathological assessment. To further our understanding of vaginal prolapse, the aim of this study was to assess the relationship between VWT and vaginal prolapse grade.

\section{Materials and methods}

Women with symptomatic prolapse were recruited over an 18-month period from the Outpatient Department of a tertiary referral centre for urogynaecology (Fig. 1). Women were excluded if pregnant, were unable to position themselves in the lithotomy position due to mobility or muscular skeletal issues, did not speak English or had any connective tissue diseases, or recent use of vaginal hormones, or previous surgery for prolapse or pessary use. Institutional Review Board approval was obtained prior to the start of the study, and all patients signed an informed consent form prior to inclusion.

Women were examined to determine their POP-Q score and ultrasonography was performed using a previously validated technique [14]. Women were scanned in the lithotomy position whilst performing a Valsalva manoeuvre, within 15 min of emptying their bladder and on confirming by ultrasonography that their bladder contained less than $50 \mathrm{ml}$ of urine. VWT was determined at the bladder neck (VWTBN), at the level of the dome of the bladder (VWTB), and at the anterior fornix (VWTAF), and at the level of the anorectal junction (VWTARJ), the rectum (VWTR) and the posterior fornix (VWTPF), posteriorly. VWT included the full thickness of tissue between the vaginal lumen and the prolapsed pelvic organ (Fig. 2). It was not possible to blind the sonographer to the POP-Q score prior to the ultrasound scan.

Women were grouped according to the severity of prolapse. In women with a POP-Q score of less than -2 , the prolapse was considered grade 0 , in women with a score of -2 to -1 as grade 1 , in women with a score of -1 to 0 as grade 2, and in women with a score greater than 1 as grade 3. Scores were compared to VWT at the three anatomical sites on the anterior and posterior vaginal walls. The primary outcome measure was the relationship between mean VWT and prolapse grade. Secondary outcome measures were the relationship between mean VWT at each of the points anteriorly or posteriorly for different grades of prolapse, and the effect of menopause status on VWT.

Statistical analysis was performed with SPSS Statistics v. 23 (IBM Corp., Armonk, NY). Parametric data were analysed using $t$ tests and nonparametric data were analysed using the Kruskal-Wallis test.
Table 1 Numbers of patients with each grade of prolapse

\begin{tabular}{llll}
\hline $\begin{array}{l}\text { Grade of } \\
\text { prolapse }\end{array}$ & $\begin{array}{l}\text { Anterior } \\
\text { compartment }(n)\end{array}$ & $\begin{array}{l}\text { Posterior } \\
\text { compartment }(n)\end{array}$ & $\begin{array}{l}\text { Central } \\
\text { compartment }(n)\end{array}$ \\
\hline 0 & 0 & 0 & 182 \\
1 & 164 & 163 & 14 \\
2 & 23 & 33 & 17 \\
3 & 55 & 45 & 22 \\
\hline
\end{tabular}

The median grade of prolapse in the anterior compartment was 1 , in the posterior compartment was 1 , and central compartment was 0
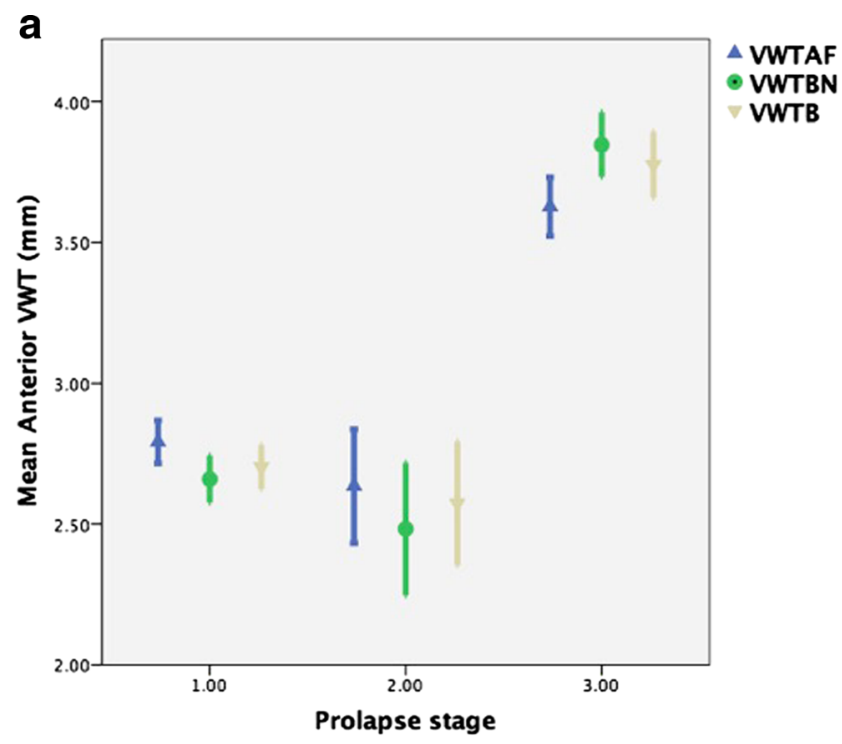

b

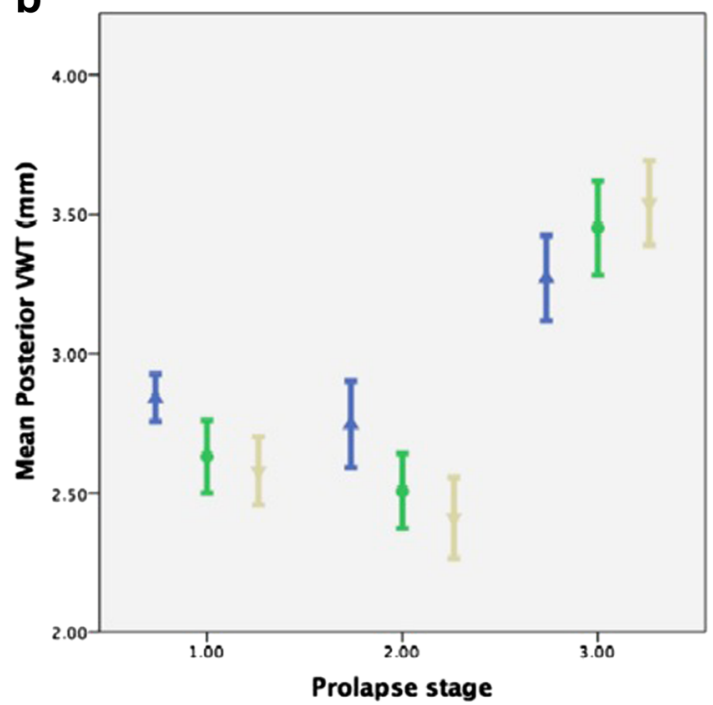

$\triangle$ WTPF

- WWTR

WWTARJ

Fig. 3 Vaginal wall thickness $(V W T)$ in relation to prolapse grade. a Anterior compartment with prolapse graded according to POP-Q score at point $\mathrm{Aa}(p<0.001)$ : fornix $(V W T A F)$, bladder neck $(V W T B N)$, and bladder $(V W T B)$. b Posterior compartment with prolapse graded according to POP-Q score at point Ap $(p<0.001)$ : anorectal junction $(V W T A R J)$, rectum $(V W T B)$, and fornix $(V W T P F)$. The data are presented as means with error bars indicating $95 \%$ confidence intervals 
Table 2 Vaginal wall thickness at each of the six points. Mean and $95 \% \mathrm{CI}$ shown

\begin{tabular}{|c|c|c|c|c|c|c|c|}
\hline \multirow[t]{3}{*}{ Measurement point } & \multicolumn{6}{|c|}{ Vaginal wall thickness (mm) } & \multirow{3}{*}{$\begin{array}{l}p \text { value } \\
\text { (Kruskal-Wallis test) }\end{array}$} \\
\hline & \multicolumn{2}{|c|}{ Prolapse grade 1} & \multicolumn{2}{|c|}{ Prolapse grade 2} & \multicolumn{2}{|c|}{ Prolapse grade 3} & \\
\hline & Mean & $\begin{array}{l}95 \% \text { confidence } \\
\text { interval }\end{array}$ & Mean & $\begin{array}{l}95 \% \text { confidence } \\
\text { interval }\end{array}$ & Mean & $\begin{array}{l}95 \% \text { confidence } \\
\text { interval }\end{array}$ & \\
\hline \multicolumn{8}{|l|}{ Anterior compartment } \\
\hline Bladder neck & 2.66 & $2.58-2.74$ & 2.48 & $2.25-2.72$ & 3.85 & $3.73-3.96$ & $<0.0001$ \\
\hline Bladder & 2.70 & $2.62-2.78$ & 2.57 & $2.35-2.79$ & 3.78 & $3.66-3.89$ & $<0.0001$ \\
\hline Fornix & 2.79 & $2.72-2.87$ & 2.63 & $2.43-2.83$ & 3.63 & $3.52-3.73$ & $<0.0001$ \\
\hline$p$ value (Friedman test) & \multicolumn{2}{|c|}{$<0.0001$} & \multicolumn{2}{|c|}{$<0.029$} & \multicolumn{2}{|c|}{$<0.0001$} & \\
\hline \multicolumn{8}{|l|}{ Posterior compartment } \\
\hline Anorectal junction & 2.58 & $2.46-2.70$ & 2.41 & $2.26-2.56$ & 3.54 & $3.39-3.69$ & $<0.0001$ \\
\hline Rectum & 2.63 & $2.50-2.76$ & 2.51 & $2.37-2.64$ & 3.54 & $3.39-3.69$ & $<0.0001$ \\
\hline Fornix & 2.84 & $2.76-2.92$ & 2.75 & $2.59-2.90$ & 3.27 & $3.12-3.42$ & $<0.0001$ \\
\hline$p$ value (Friedman test) & \multicolumn{2}{|c|}{$<0.0001$} & \multicolumn{2}{|c|}{$<0.0001$} & \multicolumn{2}{|c|}{$<0.0001$} & \\
\hline
\end{tabular}

Measurements at each point are significantly different between grades of prolapse

\section{Results}

A total of 243 women were recruited. Their mean age was 59.7 years (SD 12.0 years, range $38-84$ years), and their average grades of prolapse were 1 in the anterior compartment, 0 in the central compartment and 1 in the posterior compartment 1 (Table 1). The mean VWT at each point on the anterior and posterior vaginal walls for each grade of prolapse are shown in Fig. 3 and Table 2. For each point on the anterior and posterior vaginal walls, the mean VWT reduced as prolapse grade increased until the prolapse extended beyond the hymen $(p<0.001$; Fig. 3 , Table 2$)$. In grades 1 and 2 prolapse, anteriorly the vaginal wall was thickest at the anterior fornix, followed by the bladder, followed by the bladder neck. This pattern was reversed in patients with grade 3 prolapse. The same pattern was also observed in the posterior vaginal wall ( $p<0.05$; Table 2$)$. In both the anterior and posterior compartments, VWT at each point was significantly higher in grade 3 prolapse than in grades 1 and 2 prolapse combined ( $p<0.001$, Kruskal Wallis; Table 3$)$.

Menopause status did not have a significant effect on VWT (Table 4). We did not compare the anterior and posterior measurements as the forces and organs involved are different.

\section{Discussion}

Our results show that VWT is related to the grade of vaginal prolapse. For prolapses that have not descended further than the hymen, VWT decreases with increasing grade, and for those that extend beyond the hymen, VWT increases. We also observed that VWT was significantly less in women with grade 1 or 2 prolapse combined than in those with grade 3 prolapse.
VWT increased caudally in women with grade 1 or 2 prolapse, and decreased caudally in women with grade 3 prolapse.

No studies have examined VWT in patients with different grades of prolapse. However, in line with our results, a study comparing VWT in premenopausal and postmenopausal women with grade 1 or 2 prolapse showed a significantly greater epithelial thickness in the proximal segment of the posterior wall than in the distal segment [15]. Hsu et al. used MRI to investigate VWT, cross-sectional area and perimeter in women with and without prolapse, and found no differences [16]. The prolapse group comprised 25 women with prolapse of the vaginal wall or with the cervix at least $2 \mathrm{~cm}$ beyond the introitus (grade 3 prolapse). Interestingly in both patients with and without prolapse there was a trend for VWT to increase caudally. This is in accordance with our findings in women with grade 1 or 2 prolapse, but is opposite to our findings in in women with grade 3 prolapse in whom VWT increased towards the introitus. The mean values of VWT acquired were much higher than our values in women with grade 3 prolapse,

Table 3 Vaginal wall thickness at each measurement point comparing prolapse grades $1+2$ and prolapse grade 3

\begin{tabular}{llll}
\hline Measurement point & $\begin{array}{l}\text { Vaginal wall thickness } \\
(\text { mean, mm) }\end{array}$ & $\begin{array}{l}p \text { value } \\
\text { (Kruskal-Wallis test) }\end{array}$ \\
\cline { 2 - 3 } & Grades 1+2 & Grade 3 & \\
\hline Bladder neck & 2.64 & 3.85 & $<0.001$ \\
Bladder & 2.69 & 3.78 & $<0.001$ \\
Anterior fornix & 2.77 & 3.63 & $<0.001$ \\
Anorectal junction & 2.56 & 3.06 & $<0.001$ \\
Rectum & 2.61 & 3.05 & $<0.001$ \\
Posterior fornix & 2.79 & 3.05 & $<0.001$ \\
\hline
\end{tabular}


Table 4 Effect of menopause status on vaginal wall thickness

\begin{tabular}{llll}
\hline Measurement point & \multicolumn{1}{l}{ Vaginal wall thickness (mean, mm $)$} & $\begin{array}{l}p \text { value } \\
(t \text { test })\end{array}$ \\
\cline { 2 - 3 } & $\begin{array}{l}\text { Premenopausal } \\
(n=65)\end{array}$ & $\begin{array}{l}\text { Postmenopausal } \\
(n=178)\end{array}$ & \\
\hline Bladder neck & 2.90 & 2.91 & 0.56 \\
Bladder & 2.90 & 2.94 & 0.79 \\
Anterior fornix & 2.96 & 2.97 & 0.65 \\
Anorectal junction & 2.75 & 2.71 & 0.91 \\
Rectum & 2.75 & 2.75 & 0.77 \\
Posterior fornix & 2.77 & 2.91 & 0.17 \\
\hline
\end{tabular}

ranging from $11.6 \mathrm{~mm}$ at the introitus to $15.8 \mathrm{~mm}$ at the apex; however, the measurements taken (midsagittal diameter) included both the anterior and the posterior vaginal wall. Even taking this into account, the measurements are greater than those found in our study and those seen in histopathological studies [14]. This study was also limited by the fact that measurements were analysed after the images were acquired.

Our findings do not allow comment on the architecture or composition of the vaginal tissue, but morphometric analysis of the smooth muscle component of the vaginal wall has shown a trend for increased thickness in prolapse of grade 3 and above. A study looking at women with posthysterectomy apical vaginal wall prolapse and posterior wall prolapse to the hymen found that in tissue excised from the leading edge of the enterocele, the mean vaginal wall muscularis thickness was $3.5 \pm 1.4 \mathrm{~mm}$ compared with $2.8 \pm 0.9 \mathrm{~mm}$ in women without prolapse. The vast majority of prolapse patients in this study had grade 3 and 4 prolapse [9]. Conversely, in a study by Boreham et al., women with prolapse of the posterior vaginal wall demonstrated a decreased fractional area of smooth muscle compared with controls [17], but the authors did not comment on the total VWT. The tissue examined was taken from the apex of the posterior wall, which would correspond, to VWTPF in this study. The fraction of smooth muscle in the muscularis was most diminished in women with grade 3 prolapse, and this finding may correlate with our finding that VWT decreased caudally in women with grade 3 prolapse. The same authors reported similar findings for the anterior vaginal wall $[17,18]$. This may be due to increased apoptosis of smooth muscle cells, with studies demonstrating reduced smooth muscle and an increased apoptosis index in women with anterior vaginal wall prolapse compared with women without prolapse [19].

This decrease in smooth muscle can be associated with an increase in the fractional area of connective tissue [20, 21]. In a group of patients with mostly grade 3 prolapse, tissue from the prolapsed anterior wall demonstrated decreased smooth muscle content in the muscularis but increased thickening of the subepithelium/subepethelial collagen fibres [21].
Prolapsed vaginal epithelial tissue has also been found to show reduced total collagen and decreased collagen solubility, but increased collagen turnover [22]. This may explain the thickening we found in tissues beyond the hymen.

In another study comparing vaginal tissue taken from areas of prolapse and tissue taken from nonprolapsed areas, prolapsed tissues demonstrated an increase in collagen III and elastin, as well as increases in smooth muscle cells and collagen cross-linkages (which result in collagens that are brittle and susceptible to rupture) [23]. Collagen III is weaker than collagen I, and this change and is thought to result in thinner collagen fibres with diminished biochemical strength. This change is typical in tissues which are remodelling to adapt to a progressively increasing mechanical load [24]. Elastin is known to modulate the mechanical properties of supportive tissues, and so it has been examined in prolapse. Decreased expression and disordered elastic fibre homeostasis has been attributed to prolapse [25-28]. These findings, along with our own, strengthen the theory of decreased pelvic support leading to prolapse. Interestingly we found no difference in VWT according to menopausal status. This may not be surprising as the literature is conflicting on this topic with some studies showing an increase in VWT in postmenopausal women with prolapse and others showing a decrease [15, 17, 18, 29]. Changes in the vaginal environment including $\mathrm{pH}$, secretions and temperature may also contribute to the changes seen in grade 3 prolapse.

The limitations of our study relate to the lack of body mass index and parity data in our subjects. It was also not possible to blind the sonographer to the grade of prolapse.

\section{Conclusions}

This work adds to the body of work on the aetiology of POP. In women with vaginal prolapse, VWT is less if the prolapse has not descended further than the hymen than if it extends beyond the hymen, and in the latter case VWT is comparable to that in women without prolapse. This may be explained by changes in the vaginal tissue including collagen, elastin and smooth muscle, as well as fibrosis in exposed tissues, rather than by defects in the vagina.

\section{Compliance with ethical standards}

Conflicts of interest Rhiannon Bray: None. Alex Derpapas: Travel expenses, Astellas, Pfizer. Ruwan Fernando: Speaker, consultant and paid investigator for Pfizer. Speaker and consultant for Astellas Pharma and Allergan. Vik Khullar: Speaker, consultant and paid investigator for Pfizer. Speaker and consultant for Astellas Pharma and Allergan. Demetri C. Panayi: Speaker and consultant for Astellas Pharma. 
Open Access This article is distributed under the terms of the Creative Commons Attribution 4.0 International License (http:// creativecommons.org/licenses/by/4.0/), which permits unrestricted use, distribution, and reproduction in any medium, provided you give appropriate credit to the original author(s) and the source, provide a link to the Creative Commons license, and indicate if changes were made.

\section{References}

1. Haylen BT, Maher CF, Barber MD, Camargo S, Dandolu V, Digesu A, et al. An International Urogynecological Association (IUGA)/ International Continence Society (ICS) joint report on the terminology for female pelvic organ prolapse (POP). Int Urogynecol J. 2016;27(2):165-194.

2. Barber MD, Maher C. Epidemiology and outcome assessment of pelvic organ prolapse. Int Urogynecol J. 2013;24(11):1783-1790.

3. Kerkhof MH, Hendriks L, Brolmann HA. Changes in connective tissue in patients with pelvic organ prolapse - a review of the current literature. Int Urogynecol J Pelvic Floor Dysfunct. 2009;20(4): 461-474.

4. Chen B, Yeh J. Alterations in connective tissue metabolism in stress incontinence and prolapse. J Urol. 2011;186(5):1768-1772.

5. Digesu GA, Chaliha C, Salvatore S, Hutchings A, Khullar V. The relationship of vaginal prolapse severity to symptoms and quality of life. BJOG. 2005;112(7):971-976.

6. Nygaard I, Barber MD, Burgio KL, Kenton K, Meikle S, Schaffer J, et al. Prevalence of symptomatic pelvic floor disorders in US women. JAMA. 2008;300(11):1311-1316.

7. Richardson AC, Lyon JB, Williams NL. A new look at pelvic relaxation. Am J Obstet Gynecol. 1976;126(5):568-573.

8. Huddleston HT, Dunnihoo DR, Huddleston PM, Meyers PC. Magnetic resonance imaging of defects in DeLancey's vaginal support levels I, II, and III. Am J Obstet Gynecol. 1995;172(6):17781782. discussion 82-4.

9. Tulikangas PK, Walters MD, Brainard JA, Weber AM. Enterocele: is there a histologic defect? Obstet Gynecol. 2001;98(4):634-7.

10. Weber AM, Walters MD. Anterior vaginal prolapse: review of anatomy and techniques of surgical repair. Obstet Gynecol. 1997;89(2): 311-8.

11. Kurman RJ, Hedrick Ellenson L, Ronnett BM, Blaustein A. Blaustein's pathology of the female genital tract. 6th ed. New York: Springer; 2011.

12. Farrell SA, Dempsey T, Geldenhuys L. Histologic examination of "fascia" used in colporrhaphy. Obstet Gynecol. 2001;98(5 Pt 1): 794-798.

13. Khullar V, Salvatore S, Cardozo L, Bourne TH, Abbott D, Kelleher C. A novel technique for measuring bladder wall thickness in women using transvaginal ultrasound. Ultrasound Obstet Gynecol. 1994;4(3):220-223.

14. Panayi DC, Digesu GA, Tekkis P, Fernando R, Khullar V. Ultrasound measurement of vaginal wall thickness: a novel and reliable technique. Int Urogynecol J. 2010;21(10):1265-1270.
15. da Silva Lara LA, da Silva AR, Rosa-E-Silva JC, Chaud F, Silvade-Sá MF, Meireles E Silva AR, et al. Menopause leading to increased vaginal wall thickness in women with genital prolapse: impact on sexual response. J Sex Med. 2009;6(11):3097-3110.

16. Hsu Y, Chen L, Delancey JO, Ashton-Miller JA. Vaginal thickness, cross-sectional area, and perimeter in women with and those without prolapse. Obstet Gynecol. 2005;105(5 Pt 1):1012-1017.

17. Boreham MK, Wai CY, Miller RT, Schaffer JI, Word RA. Morphometric properties of the posterior vaginal wall in women with pelvic organ prolapse. Am J Obstet Gynecol. 2002;187(6): 1501-1508. discussion 8-9.

18. Boreham MK, Wai CY, Miller RT, Schaffer JI, Word RA. Morphometric analysis of smooth muscle in the anterior vaginal wall of women with pelvic organ prolapse. Am J Obstet Gynecol. 2002;187(1):56-63.

19. Takacs P, Gualtieri M, Nassiri M, Candiotti K, Medina CA. Vaginal smooth muscle cell apoptosis is increased in women with pelvic organ prolapse. Int Urogynecol J Pelvic Floor Dysfunct. 2008;19(11):1559-1564.

20. Badiou W, Granier G, Bousquet PJ, Monrozies X, Mares P, de Tayrac R. Comparative histological analysis of anterior vaginal wall in women with pelvic organ prolapse or control subjects. A pilot study. Int Urogynecol J Pelvic Floor Dysfunct. 2008;19(5):723-9.

21. Inal HA, Kaplan PB, Usta U, Tastekin E, Aybatli A, Tokuc B. Neuromuscular morphometry of the vaginal wall in women with anterior vaginal wall prolapse. Neurourol Urodyn. 2010;29(3):458 463.

22. Jackson SR, Avery NC, Tarlton JF, Eckford SD, Abrams P, Bailey AJ. Changes in metabolism of collagen in genitourinary prolapse. Lancet. 1996;347(9016):1658-1661.

23. Kerkhof MH, Ruiz-Zapata AM, Bril H, Bleeker MC, Belien JA, Stoop R, et al. Changes in tissue composition of the vaginal wall of premenopausal women with prolapse. Am J Obstet Gynecol. 2014;210(2):168 e1-168 e9.

24. Moalli PA, Shand SH, Zyczynski HM, Gordy SC, Meyn LA. Remodeling of vaginal connective tissue in patients with prolapse. Obstet Gynecol. 2005;106(5 Pt 1):953-963.

25. Karam JA, Vazquez DV, Lin VK, Zimmern PE. Elastin expression and elastic fibre width in the anterior vaginal wall of postmenopausal women with and without prolapse. BJU Int. 2007;100(2):346350 .

26. Takacs P, Nassiri M, Viciana A, Candiotti K, Fornoni A, Medina CA. Fibulin-5 expression is decreased in women with anterior vaginal wall prolapse. Int Urogynecol J Pelvic Floor Dysfunct. 2009;20(2):207-211.

27. Drewes PG, Yanagisawa H, Starcher B, Hornstra I, Csiszar K, Marinis SI, et al. Pelvic organ prolapse in fibulin-5 knockout mice: pregnancy-induced changes in elastic fiber homeostasis in mouse vagina. Am J Pathol. 2007;170(2):578-89.

28. Chen B, Wen Y, Polan ML. Elastolytic activity in women with stress urinary incontinence and pelvic organ prolapse. Neurourol Urodyn. 2004;23(2):119-26.

29. Clobes A, DeLancey JO, Morgan DM. Urethral circular smooth muscle in young and old women. Am J Obstet Gynecol. 2008;198(5):587.e1-587.e5. 